\title{
Hymenobacter deserti sp. nov., isolated from the desert of Xinjiang, China
}

\author{
Correspondence \\ Chengxiang Fang \\ cxfang@whu.edu.cn \\ Chufu Zhang \\ cfzhang@whu.edu.cn
}

\author{
Lei Zhang, Jun Dai, Yali Tang, Xuesong Luo, Yang Wang, Hongli An, \\ Chengxiang Fang and Chufu Zhang
}

College of Life Sciences, Wuhan University, Wuhan 430072, PR China
A Gram-negative, rod-shaped, non-motile and pink-pigmented bacterium, designated strain ZLB$3^{\top}$, was isolated from a desert soil sample collected from Xinjiang Province, China, and characterized by using a polyphasic taxonomic approach. Phylogenetic analysis based on 16S rRNA gene sequences indicated that the isolate belongs to the phylum Bacteroidetes and is related to the genus Hymenobacter. $16 \mathrm{~S}$ rRNA gene sequence similarities between strain ZLB-3 ${ }^{\top}$ and the type strains of Hymenobacter species with validly published names ranged from 90.0 to $94.6 \%$. No other taxa in the phylum Bacteroidetes showed more than $90 \%$ sequence similarity to the isolate. The strain contained MK-7 as the predominant menaquinone. The major fatty acids were iso- $\mathrm{C}_{15: 0}(27.8 \%)$, anteiso- $\mathrm{C}_{17: 1} \mathrm{~B} /$ iso- $_{17: 1} \mathrm{I}(25.2 \%)$, iso- $\mathrm{C}_{17: 0}$ 3-OH (9.6\%) and $\mathrm{C}_{16: 1} \omega 7 \mathrm{c} /$ iso- $_{15: 0} 2-\mathrm{OH}(8.5 \%)$. Phosphatidylethanolamine, two unknown aminophospholipids, an unknown aminolipid, an unknown glycolipid and six unknown polar lipids were detected in the polar lipid profile. The DNA G+C content was $58.6 \mathrm{~mol} \%$. These chemotaxonomic data supported the affiliation of strain ZLB-3 ${ }^{\top}$ to the genus Hymenobacter. However, the results of physiological and biochemical tests allowed phenotypic differentiation of the isolate from recognized Hymenobacter species. On the basis of the evidence presented, it is proposed that strain ZLB-3 ${ }^{T}$ represents a novel species, Hymenobacter deserti sp. nov. The type strain is ZLB $^{-}{ }^{\top}$ (=CCTCC AB $207171^{\top}=$ NRRL B-51267 ${ }^{\top}$ ).
The genus Hymenobacter was first described by Hirsch et al. (1998) and its description was subsequently emended by Buczolits et al. (2006). At the time of writing, it comprises 11 recognized species, including the recently described species Hymenobacter soli (Kim et al., 2008) and Hymenobacter psychrotolerans (Zhang et al., 2008). In this study, we report a pink-pigmented bacterial strain, $Z \mathrm{LB}-3^{\mathrm{T}}$, isolated from a desert area in Xinjiang Province, PR China, in the course of environmental investigation. On the basis of phenotypic characteristics, chemotaxonomic data and phylogenetic analysis of the 16S rRNA gene sequence, the isolate represents a novel species of Hymenobacter.

Strain ZLB-3 ${ }^{\mathrm{T}}$ was isolated from a desert soil sample. The soil sample was thoroughly suspended in sterilized water and the suspension was spread on tenfold-diluted tryptic soy broth $(0.1 \times \mathrm{TSB})$ agar plates $\left[3.0 \mathrm{~g}\right.$ TSB (Difco) $1^{-1}$ solidified with $15.0 \mathrm{~g}$ agar $\mathrm{l}^{-1}, \mathrm{pH}$ 7.0] after serial dilution with sterilized water. Isolation was achieved after incubation at $28{ }^{\circ} \mathrm{C}$ for 1 week. Isolate $\mathrm{ZLB}-3^{\mathrm{T}}$ was routinely

The GenBank/EMBL/DDBJ accession number for the 16S rRNA gene sequence of strain ZLB-3 $^{\top}$ is EU325941. cultivated on the same medium at $30{ }^{\circ} \mathrm{C}$ and stored as a glycerol suspension $(20 \%, \mathrm{v} / \mathrm{v})$ at $-80{ }^{\circ} \mathrm{C}$.

Chromosomal DNA was isolated and purified by using a Bacteria Genomic DNA isolation kit (ChaoShi-Bio). Primers 27f (5'-GAGTTTGATCCTGGCTCAG-3') and 1527r (5'-AGAAAGGAGGTGATCCAGCC-3') were used for amplification of the 16S rRNA gene (Lane, 1991). PCR and 16S rRNA gene sequencing were carried out as described by Lin et al. (2004). An almost-complete 16S rRNA gene sequence was obtained (1427 bp) and compared with sequences deposited in the GenBank database. The sequences were aligned using CLUSTAL_X software (Thompson et al., 1997) and distances were calculated according to Kimura's two-parameter method (Kimura, 1980). Phylogenetic trees were inferred using the neighbour-joining method (Saitou \& Nei, 1987) and bootstrap analysis was performed, based on 1000 resamplings (Felsenstein, 1985). The MEGA package version 3.1 (Kumar et al., 2004) was used for all analyses.

Comparative $16 \mathrm{~S}$ rRNA gene sequence analysis showed that strain $\mathrm{ZLB}-3^{\mathrm{T}}$ was most closely related to members of the 
genus Hymenobacter. In a phylogenetic tree based on the neighbour-joining algorithm, strain $\mathrm{ZLB}-3^{\mathrm{T}}$ joined the clade comprising Hymenobacter species at a bootstrap confidence value of $100 \%$ (Fig. 1). Strain ZLB-3 ${ }^{\mathrm{T}}$ showed the highest 16S rRNA gene sequence similarity to Hymenobacter ocellatus Myx $2105^{\mathrm{T}}(94.6 \%)$; this value is well below the threshold for demarcating bacterial species (Stackebrandt \& Goebel, 1994). 16S rRNA gene sequence similarities between strain $\mathrm{ZLB}-3^{\mathrm{T}}$ and the type strains of other Hymenobacter species ranged from 90.0 to $92.3 \%$. No other recognized bacterial species showed more than $90 \% 16 \mathrm{~S}$ rRNA gene sequence similarity to the new isolate. These results suggest that strain $\mathrm{ZLB}-3^{\mathrm{T}}$ represents a novel species within the genus Hymenobacter.

Cell morphology was examined by using phase-contrast microscopy (BX51 microscope; Olympus). The Gram reaction was carried out according to the classical Gram procedure described by Doetsch (1981). Gliding motility was examined as described by Bowman (2000). Growth was assessed at $4,10,25,30,37,40$ and $42{ }^{\circ} \mathrm{C}$, at $\mathrm{pH} 4-11$ (increments of $1 \mathrm{pH}$ unit) and at $0,1,2,3,5$ and $10 \%$ $\mathrm{NaCl}$. Oxidase activity was tested using a $1 \%$ solution of tetramethyl-p-phenylenediamine (Kovács, 1956). Catalase activity was detected by assessing the production of bubbles after the addition of a drop of $3 \% \mathrm{H}_{2} \mathrm{O}_{2}$. Hydrolysis of starch and casein was tested as described by Smibert \& Krieg (1994). Other physiological properties and enzyme activities were tested using the API 20E, API 20NE and API ZYM systems (bioMérieux) according to the manufacturer's instructions. Antibiotic-sensitivity tests were performed by spreading bacterial suspensions on culture plates and applying discs impregnated with different antibiotics (Buczolits et al., 2002).

The ability of strain $Z \mathrm{LB}-3^{\mathrm{T}}$ to utilize 95 different compounds was tested by using the Biolog GN2 automatic identification system. In order to compare its ability to utilize carbon sources with other species of the genus Hymenobacter, the type strains of five Hymenobacter species were used as reference strains: H. ocellatus DSM $11117^{\mathrm{T}}$ and
Hymenobacter chitinivorans DSM $11115^{\mathrm{T}}$ were obtained from the Deutsche Sammlung von Mikroorganismen und Zellkulturen (Braunschweig, Germany), Hymenobacter rigui KCTC $12533^{\mathrm{T}}$ was obtained from the Korean Collection for Type Cultures (Taejon, Korea), Hymenobacter norwichensis $\mathrm{NS} / 50^{\mathrm{T}}$ was obtained from Dr Hans-Jürgen Busse (Institut für Bakteriologie, Mykologie und Hygiene, Veterinärmedizinische Universität Wien, Austria) and Hymenobacter xinjiangensis CCTCC $\mathrm{AB} 206080^{\mathrm{T}}$ was obtained from the China Center for Type Culture Collection (Wuhan, PR China). All strains were grown on $\mathrm{R} 2 \mathrm{~A}$ agar at $30{ }^{\circ} \mathrm{C}$ for $48 \mathrm{~h}$ and suspended in pre-warmed sterile GN/GP-IF medium [0.40\% NaCl, $0.03 \%$ Pluronic F68 (Sigma), $0.02 \%$ gellan gum (Sigma)] within the density range specified by the manufacturer (determined with a Biolog model 21907 photometer). Biolog GN2 MicroPlates were inoculated with $150 \mu \mathrm{l}$ cell suspension per well. Inoculated Biolog GN2 plates were incubated at $30{ }^{\circ} \mathrm{C}$ for $24 \mathrm{~h}$ and the results were read with a MicroPlate reader, using MicroLog 3 computer software to perform automated reading and identification.

Strain ZLB- $3^{\mathrm{T}}$ formed visible colonies on $0.1 \times \mathrm{TSB}$ agar after incubation at $30{ }^{\circ} \mathrm{C}$ for $48 \mathrm{~h}$. The strain grew well on nutrient-reduced media such as $0.1 \times$ TSB agar, R2A and PYES agar, but did not grow on TSA or marine agar 2216 (Difco). Colonies were pink, convex and circular. Cells were Gram-negative, strictly aerobic, non-motile, 1.1-2.5 $\mu \mathrm{m}$ long and $0.6-0.8 \mu \mathrm{m}$ wide. The physiological and biochemical characteristics of strain $\mathrm{ZLB}-3^{\mathrm{T}}$ are summarized in the species description and a comparison of selective characteristics with related type strains is given in Table 1.

The DNA G + C content of strain ZLB- $3^{\mathrm{T}}$ was determined by HPLC (UltiMate 3000; Dionex) according to the method of Mesbah et al. (1989). Respiratory quinones were extracted and identified by HPLC as described by Xie \& Yokota (2003). For fatty acid methyl ester analysis, strain ZLB- $3^{\mathrm{T}}$ and the five reference strains were grown on R2A agar at $30{ }^{\circ} \mathrm{C}$ for $48 \mathrm{~h}$. Fatty acids were extracted, methylated and analysed according to the standard

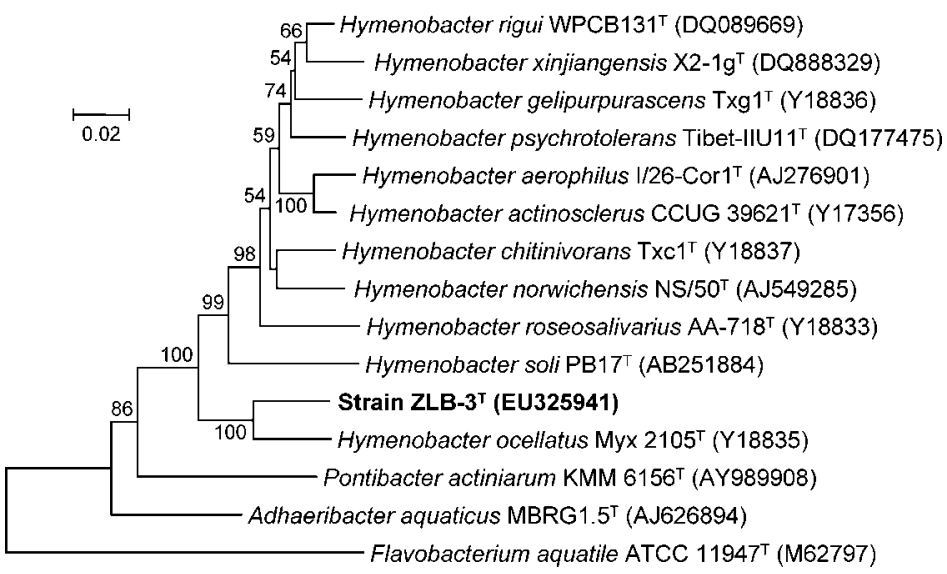

Fig. 1. Neighbour-joining phylogenetic tree, based on 16S rRNA gene sequences, showing the relationships of strain $Z \mathrm{LB}-3^{\top}$ and related taxa. Bootstrap values (1000 replications) are shown as percentages at each node only if they are $50 \%$ or greater. The sequence of Flavobacterium aquatile ATCC $11947^{\top}$ was used as an outgroup. Bar, 0.02 substitutions per nucleotide position. 
Table 1. Phenotypic characteristics that differentiate strain ZLB-3 $3^{\top}$ from related members of the genus $H y m e n o b a c t e r$

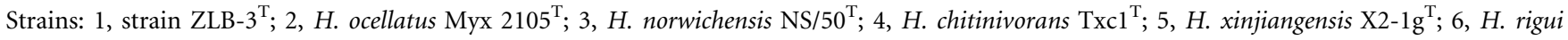
WPCB $131^{\mathrm{T}}$. Data were taken from Buczolits et al. (2006), Baik et al. (2006), Zhang et al. (2007) and this study. All data for single carbon-source utilization on Biolog GN2 plates were taken from this study using the strains indicated in the text. +, Positive; - , negative; $(+)$, weakly positive; $\mathrm{NR}$, not reported. All strains were negative for $\alpha$-galactosidase and $\beta$-galactosidase.

\begin{tabular}{|c|c|c|c|c|c|c|}
\hline Characteristic & 1 & 2 & 3 & 4 & 5 & 6 \\
\hline \multicolumn{7}{|l|}{ Growth at/in: } \\
\hline $4{ }^{\circ} \mathrm{C}$ & $(+)$ & - & $(+)$ & + & + & + \\
\hline $1 \% \mathrm{NaCl}$ & $(+)$ & + & - & $(+)$ & - & + \\
\hline $3 \% \mathrm{NaCl}$ & - & + & - & $(+)$ & - & - \\
\hline \multicolumn{7}{|c|}{ Carbon-source utilization on Biolog GN2 } \\
\hline Cellobiose & $(+)$ & - & $(+)$ & - & + & + \\
\hline i-Erythritol & + & - & - & - & + & - \\
\hline Gentiobiose & - & $(+)$ & - & $(+)$ & - & + \\
\hline Lactulose & $(+)$ & - & + & - & + & - \\
\hline D-Mannose & + & $(+)$ & + & - & $(+)$ & - \\
\hline Trehalose & + & - & $(+)$ & $(+)$ & + & + \\
\hline L-Serine & + & - & - & - & + & - \\
\hline Glucose 6-phosphate & $(+)$ & - & - & $(+)$ & - & $(+)$ \\
\hline \multicolumn{7}{|l|}{ Enzyme activity (API ZYM) } \\
\hline Esterase (C4) & - & - & $(+)$ & $(+)$ & + & + \\
\hline Valine arylamidase & + & - & $(+)$ & - & + & + \\
\hline Cystine arylamidase & + & - & - & - & + & $(+)$ \\
\hline Acid phosphatase & + & - & $(+)$ & - & + & + \\
\hline$\alpha$-Glucosidase & - & - & - & - & - & + \\
\hline$N$-Acetyl- $\beta$-glucosaminidase & + & - & - & - & + & + \\
\hline$\alpha$-Mannosidase & - & - & - & - & + & - \\
\hline DNA G $+\mathrm{C}$ content $(\mathrm{mol} \%)$ & 58.6 & 65 & NR & 61 & 54 & 65 \\
\hline
\end{tabular}

protocol of the Sherlock Microbial Identification System (MIDI). Polar lipids were extracted and analysed as described by Tindall (1990) and Ventosa et al. (1993).

The DNA G + C content of strain ZLB- $3^{\mathrm{T}}$ was $58.6 \mathrm{~mol} \%$, which is consistent with the range reported for the genus Hymenobacter (55-65 mol\%; Buczolits et al., 2006). The predominant isoprenoid quinone was MK-7. The major fatty acids were iso- $\mathrm{C}_{15: 0}(27.8 \%)$, summed feature 4 (anteiso$\mathrm{C}_{17: 1} \mathrm{~B} /$ iso- $\left.\mathrm{C}_{17: 1} \mathrm{I}\right)(25.2 \%)$, iso- $\mathrm{C}_{17: 0} 3-\mathrm{OH}(9.6 \%)$ and summed feature $3\left(\mathrm{C}_{16: 1} \omega 7 \mathrm{c} /\right.$ iso- $\left.\mathrm{C}_{15: 0} 2-\mathrm{OH}\right)(8.5 \%)$. The fatty acid profile of the new isolate was similar to those of Hymenobacter species. However, some obvious quantitative differences were observed. The novel strain differed from the other Hymenobacter species especially in the relative amounts of iso- $\mathrm{C}_{17: 0} 3-\mathrm{OH}, \mathrm{C}_{16: 1} \omega 5 \mathrm{c}$, anteiso- $\mathrm{C}_{15: 0}$ and summed feature 3. Detailed fatty acid profiles are shown in Table 2. The polar lipid profile (Fig. 2) consisted mainly of phosphatidylethanolamine, two unknown aminophospholipids (APL1, APL2) and an unknown polar lipid (L3). An unknown aminolipid (AL1), an unknown glycolipid (GL1) and three unknown polar lipids $(\mathrm{L} 2,5,6)$ occurred at moderate levels. Trace amounts of two further unknown polar lipids $(\mathrm{L} 1,4)$ were also detected. The polar lipid profile may be useful for confirming strain $\mathrm{ZLB}-3^{\mathrm{T}}$ as a representative of a novel species within the genus Hymenobacter.

In summary, the characteristics of strain $\mathrm{ZLB}-3^{\mathrm{T}}$ are consistent with the description of the genus Hymenobacter with regard to morphological, biochemical and chemotaxonomic properties. However, on the basis of phylogenetic distance from known Hymenobacter species indicated by $16 \mathrm{~S}$ rRNA gene sequence similarities and the combination of unique phenotypic characteristics (Table 1), strain ZLB- $3^{\mathrm{T}}$ should be placed in the genus Hymenobacter as a representative of a novel species, for which the name Hymenobacter deserti sp. nov. is proposed.

\section{Description of Hymenobacter deserti sp. nov.}

Hymenobacter deserti (de.ser'ti. L. gen. n. deserti of a desert).

Cells are Gram-negative, rod-shaped, non-spore-forming, $1.1-2.5 \mu \mathrm{m}$ long and $0.6-0.8 \mu \mathrm{m}$ wide. Motility is not 
Table 2. Cellular fatty acid compositions of the type strains of Hymenobacter species

Strains: 1, strain ZLB-3 ${ }^{\mathrm{T}}$ (data from this study); 2, H. ocellatus DSM $11117^{\mathrm{T}}$ (this study); 3, H. soli PB17 ${ }^{\mathrm{T}}$ (Kim et al., 2008); 4, H. roseosalivarius AA$718^{\mathrm{T}}$ (Buczolits et al., 2002); 5, H. norwichensis $\mathrm{NS} / 50^{\mathrm{T}}$ (this study); 6, H. chitinivorans DSM $11115^{\mathrm{T}}$ (this study); 7, H. actinosclerus CCUG $39621^{\mathrm{T}}$ (Buczolits et al., 2002); 8, H. aerophilus I/26-Corl ${ }^{\mathrm{T}}$ (Buczolits et al., 2002); 9, H. psychrotolerans Tibet-IIU11 ${ }^{\mathrm{T}}$ (Zhang et al., 2008); 10, H.

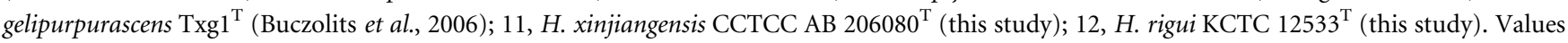
are percentages of total fatty acids; only fatty acids accounting for more than $0.5 \%$ in at least one of the strains are indicated. ND, Not detected/not reported.

\begin{tabular}{|c|c|c|c|c|c|c|c|c|c|c|c|c|}
\hline Fatty acid & 1 & 2 & 3 & 4 & 5 & 6 & 7 & 8 & 9 & 10 & 11 & 12 \\
\hline $\mathrm{C}_{14: 0}$ & $\mathrm{ND}$ & $\mathrm{ND}$ & 1.2 & ND & 1.6 & 1.1 & $\mathrm{ND}$ & $\mathrm{ND}$ & 0.8 & $\mathrm{ND}$ & 0.9 & 1.0 \\
\hline iso- $\mathrm{C}_{14: 0}$ & 0.1 & 0.5 & $\mathrm{ND}$ & ND & 0.3 & 0.4 & $\mathrm{ND}$ & ND & $\mathrm{ND}$ & $\mathrm{ND}$ & 0.7 & 0.3 \\
\hline iso- $\mathrm{C}_{15: 1} \mathrm{G}$ & 0.3 & 0.7 & $\mathrm{ND}$ & ND & 0.9 & 0.7 & $\mathrm{ND}$ & ND & 1.8 & 0.8 & ND & $\mathrm{ND}$ \\
\hline anteiso- $\mathrm{C}_{15: 1} \mathrm{~A}$ & 0.1 & 0.5 & ND & ND & 0.4 & 0.3 & ND & ND & 0.6 & 1.1 & 0.3 & 0.2 \\
\hline iso- $\mathrm{C}_{15: 0}$ & 27.8 & 27.5 & 51.8 & 8.3 & 18.9 & 22.3 & 22.3 & 10.8 & 24.5 & 17.3 & 22.5 & 25.1 \\
\hline anteiso- $C_{15: 0}$ & 1.6 & 6.8 & 6.2 & ND & 6.8 & 6.4 & 25.8 & 22.3 & 8.4 & 23.1 & 4.6 & 5.2 \\
\hline iso- $\mathrm{C}_{16: 1} \mathrm{H}$ & 1.1 & 0.8 & 1.0 & 2.7 & 1.6 & 2.3 & 1.5 & 1.5 & 1.2 & 3.7 & 2.4 & 1.7 \\
\hline iso- $\mathrm{C}_{16: 0}$ & 0.8 & 0.9 & $\mathrm{ND}$ & 2.1 & 0.8 & 1.5 & $\mathrm{ND}$ & 0.8 & 2.1 & 2.7 & 1.8 & 0.7 \\
\hline $\mathrm{C}_{16: 1} \omega 5 c$ & 4.9 & 7.5 & 11.0 & 23.3 & 12.5 & 15.2 & 3.7 & 7.9 & 12.7 & 11.3 & 20.5 & 14.2 \\
\hline $\mathrm{C}_{16: 0}$ & 2.0 & 0.6 & 4.2 & 1.1 & 2.6 & 1.4 & ND & 1.7 & 2.3 & ND & 1.3 & 2.1 \\
\hline iso- $\mathrm{C}_{15: 0} 3-\mathrm{OH}$ & 5.1 & 3.5 & 2.1 & 2.7 & 3.1 & 2.9 & 1.6 & 1.6 & 2.7 & 2.3 & 3.2 & 4.1 \\
\hline iso- $\mathrm{C}_{17: 1} \omega 9 c$ & 0.7 & 1.1 & $\mathrm{ND}$ & ND & 0.2 & 0.7 & ND & ND & $\mathrm{ND}$ & $\mathrm{ND}$ & 0.2 & 0.2 \\
\hline iso- $\mathrm{C}_{17: 0}$ & 2.1 & 3.1 & 1.1 & 1.7 & 2.3 & 1.8 & 1.8 & 4.5 & 0.4 & 1.7 & 1.3 & 1.9 \\
\hline anteiso- $\mathrm{C}_{17: 0}$ & 0.4 & 0.9 & $\mathrm{ND}$ & ND & 0.5 & 0.4 & 0.7 & 2.3 & $\mathrm{ND}$ & 2.0 & 0.3 & 0.3 \\
\hline $\mathrm{C}_{17: 1} \omega 6 c$ & 0.8 & 1.2 & $\mathrm{ND}$ & 1.1 & 0.6 & 0.8 & 0.7 & $\mathrm{ND}$ & ND & $\mathrm{ND}$ & 0.6 & 0.4 \\
\hline iso- $\mathrm{C}_{16: 0} 3-\mathrm{OH}$ & 0.6 & 0.3 & $\mathrm{ND}$ & 1.0 & 0.3 & 0.3 & $\mathrm{ND}$ & $\mathrm{ND}$ & ND & $\mathrm{ND}$ & 0.4 & 0.2 \\
\hline $\mathrm{C}_{16: 0} 3-\mathrm{OH}$ & 0.6 & 0.4 & 1.0 & 1.2 & 0.8 & 0.9 & $\mathrm{ND}$ & ND & 1.4 & $\mathrm{ND}$ & 1.3 & 1.0 \\
\hline iso- $\mathrm{C}_{17: 0} 3-\mathrm{OH}$ & 9.6 & 7.0 & 1.2 & 5.8 & 4.3 & 4.1 & 3.1 & 3.5 & 3.5 & 3.7 & 4.5 & 4.5 \\
\hline $\mathrm{C}_{17: 0} 2-\mathrm{OH}$ & 0.3 & 0.2 & $\mathrm{ND}$ & ND & 0.4 & 0.3 & 2.0 & 1.3 & $\mathrm{ND}$ & 1.7 & 0.3 & 0.2 \\
\hline Summed feature $2^{\star}$ & 1.8 & 2.6 & 0.9 & ND & 1.4 & 1.5 & 2.3 & 0.8 & 1.5 & $\mathrm{ND}$ & 1.0 & 2.5 \\
\hline Summed feature $3^{*}$ & 8.5 & 9.6 & 14.4 & 29.8 & 24.1 & 15.0 & 13.1 & 21.4 & 20.0 & 17.6 & 19.9 & 15.8 \\
\hline Summed feature $4^{*}$ & 25.2 & 14.1 & 3.5 & 18.5 & 7.3 & 13.5 & 19.9 & 17.7 & 14.0 & 9.4 & 5.7 & 9.7 \\
\hline
\end{tabular}

${ }^{\star}$ Summed features represent groups of two or three fatty acids that could not be separated by GLC with the MIDI system. Summed feature 2 contains $\mathrm{C}_{13: 0} 3-\mathrm{OH}$ and/or iso- $\mathrm{C}_{15: 1} \mathrm{I}$; summed feature 3 contains $\mathrm{C}_{16: 1} \omega 7 \mathrm{c}$ and/or iso- $\mathrm{C}_{15: 0}$ 2-OH; summed feature 4 contains anteiso- $\mathrm{C}_{17: 1} \mathrm{~B}$ and/or iso- $\mathrm{C}_{17: 1} \mathrm{I}$.

observed. Colonies grown on $0.1 \times$ TSB agar for 5 days are circular, $1-2 \mathrm{~mm}$ in diameter, convex, pink and smooth. Growth occurs at $4-40{ }^{\circ} \mathrm{C}$ (optimum $30{ }^{\circ} \mathrm{C}$ ), $0-2 \%(w / v)$ $\mathrm{NaCl}$ (optimum $0 \%$ ) and $\mathrm{pH}$ 5-11 (optimum $\mathrm{pH}$ 7). Oxidase- and catalase-positive. Gelatin, starch and casein are hydrolysed, but aesculin is not. Nitrate reduction is weakly positive without production of $\mathrm{N}_{2} . \mathrm{H}_{2} \mathrm{~S}$, indole and acetoin (Voges-Proskauer reaction) are not produced. Activities of arginine dihydrolase, lysine decarboxylase, ornithine decarboxylase, tryptophan deaminase and urease are not detected. Biolog GN2 tests show that the type strain oxidizes $\alpha$-cyclodextrin, dextrin, glycogen, $N$-acetyl-Dglucosamine, L-arabinose, cellobiose, i-erythritol, D-fructose, D-galactose, $\alpha$-D-glucose, $\alpha$-D-lactose, lactulose, maltose, D-mannose, D-sorbitol, trehalose, turanose, monomethyl succinate, acetic acid, citric acid, D-galacturonic acid, $\alpha$-ketobutyric acid, L-alanyl glycine, Lasparagine, L-aspartic acid, L-glutamic acid, glycyl Lglutamic acid, L-serine, L-threonine, uridine and glucose 6-phosphate. Does not oxidize Tweens 40 or $80, \mathrm{~N}$-acetylD-galactosamine, adonitol, D-arabitol, L-fucose, gentio- biose, myo-inositol, D-mannitol, melibiose, methyl $\beta$-Dglucoside, D-psicose, raffinose, sucrose, cis-aconitic acid, formic acid, D-galactonic acid lactone, D-gluconic acid, Dglucosaminic acid, D-glucuronic acid, $\alpha$-, $\beta$ - or $\gamma$-hydroxybutyric acids, $p$-hydroxyphenylacetic acid, itaconic acid, $\alpha$-ketoglutaric acid, DL-lactic acid, malonic acid, propionic acid, quinic acid, D-saccharic acid, sebacic acid, succinic acid, bromosuccinic acid, succinamic acid, glucuronamide, L-alaninamide, D-alanine, L-histidine, hydroxy-L-proline, Lleucine, L-phenylalanine, L-proline, L-pyroglutamic acid, Dserine, DL-carnitine, $\gamma$-aminobutyric acid, urocanic acid, inosine, thymidine, phenylethylamine, putrescine, 2-aminoethanol, 2,3-butanediol, glycerol, DL- $\alpha$-glycerol phosphate or glucose 1-phosphate. According to the API ZYM gallery (bioMérieux), produces alkaline phosphatase, esterase lipase (C8), leucine arylamidase, valine arylamidase, cystine arylamidase, acid phosphatase, naphthol-ASBI-phosphohydrolase and $N$-acetyl- $\beta$-glucosaminidase, but not esterase (C4), lipase (C14), trypsin, $\alpha$-chymotrypsin, $\alpha$ galactosidase, $\beta$-galactosidase, $\beta$-glucuronidase, $\alpha$-glucosidase, $\beta$-glucosidase, $\alpha$-mannosidase or $\alpha$-fucosidase. 


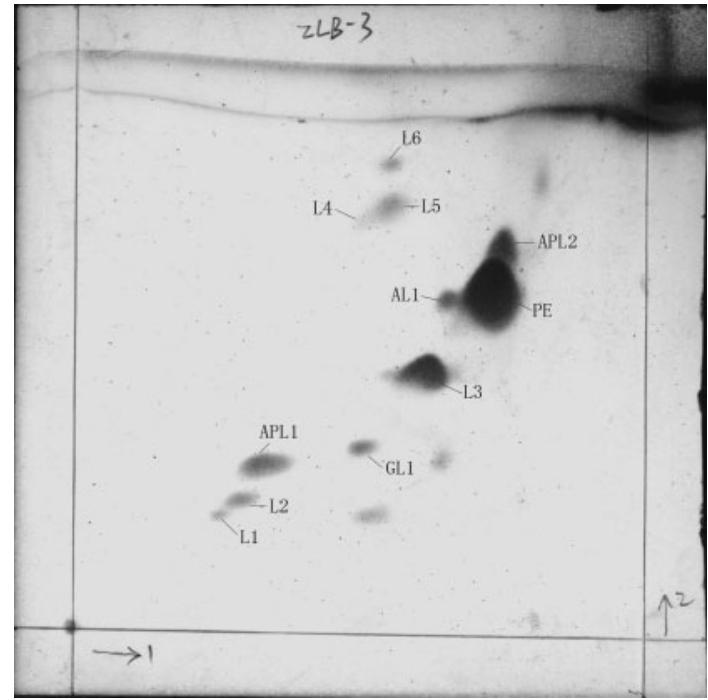

Fig. 2. Polar lipid profile of strain ZLB-3 ${ }^{\top}$ after separation in twodimensional TLC. PE, Phosphatidylethanolamine; APL1-2, unknown aminophospholipids; AL1, unknown aminolipid; GL1, unknown glycolipid; L1-6, unknown polar lipids.

Susceptible to chloramphenicol, erythromycin, gentamycin, penicillin G, polymyxin $\mathrm{B}$ sulfate, tetracycline, kanamycin and vancomycin. The predominant menaquinone is MK-7. The major fatty acids are iso- $C_{15: 0}$, summed feature 4 (anteiso- $\mathrm{C}_{17: 1} \mathrm{~B} /$ iso- $\mathrm{C}_{17: 1} \mathrm{I}$ ), iso- $\mathrm{C}_{17: 0} 3-\mathrm{OH}$ and summed feature $3\left(\mathrm{C}_{16: 1} \omega 7 \mathrm{c} /\right.$ iso- $\left.\mathrm{C}_{15: 0} 2-\mathrm{OH}\right)$. The polar lipid profile is composed of the major compound phosphatidylethanolamine and two unknown aminophospholipids, an aminolipid, a glycolipid and six polar lipids. The DNA G + C content of the type strain is $58.6 \mathrm{~mol} \%$.

The type strain, $\mathrm{ZLB}-3^{\mathrm{T}}$ (=CCTCC AB $207171^{\mathrm{T}}=\mathrm{NRRL}$ $\left.\mathrm{B}-51267^{\mathrm{T}}\right)$, was isolated from the surface layer of a desert soil from Xinjiang Province, China.

\section{Acknowledgements}

We are grateful to Dr Hans-Jürgen Busse for kindly providing the type strain of $H$. norwichensis. This work was supported by the R \& D Infrastructure and Facility Development Program from the Ministry of Science and Technology of the People's Republic of China (grant no. 2005DKA21208).

\section{References}

Baik, K. S., Seong, C. N., Moon, E. Y., Park, Y.-D., Yi, H. \& Chun, J. (2006). Hymenobacter rigui sp. nov., isolated from wetland freshwater. Int J Syst Evol Microbiol 56, 2189-2192.

Bowman, J. P. (2000). Description of Cellulophaga algicola sp. nov., isolated from the surfaces of Antarctic algae, and reclassification of Cytophaga uliginosa (ZoBell and Upham 1944) Reichenbach 1989 as Cellulophaga uliginosa comb. nov. Int J Syst Evol Microbiol 50, 1861-1868.

Buczolits, S., Denner, E. B. M., Vybiral, D., Wieser, M., Kämpfer, P. \& Busse, H.-J. (2002). Classification of three airborne bacteria and proposal of Hymenobacter aerophilus sp. nov. Int J Syst Evol Microbiol 52, 445-456.

Buczolits, S., Denner, E. B. M., Kämpfer, P. \& Busse, H.-J. (2006). Proposal of Hymenobacter norwichensis sp. nov., classification of 'Taxeobacter ocellatus', 'Taxeobacter gelupurpurascens' and 'Taxeobacter chitinovorans' as Hymenobacter ocellatus sp. nov., Hymenobacter gelipurpurascens sp. nov. and Hymenobacter chitinivorans sp. nov., respectively, and emended description of the genus Hymenobacter Hirsch et al. 1999. Int J Syst Evol Microbiol 56, 20712078.

Doetsch, R. N. (1981). Determinative methods of light microscopy. In Manual of Methods for General Bacteriology, pp. 21-33. Edited by P. Gerhardt, R. G. E. Murray, R. N. Costilow, E. W. Nester, W. A. Wood, N. R. Krieg \& G. B. Phillips. Washington, DC: American Society for Microbiology.

Felsenstein, J. (1985). Confidence limits on phylogenies: an approach using the bootstrap. Evolution 39, 783-791.

Hirsch, P., Ludwig, W., Hethke, C., Sittig, M., Hoffmann, B. \& Gallikowski, C. A. (1998). Hymenobacter roseosalivarius gen. nov., sp. nov. from continental Antarctic soils and sandstone: bacteria of the Cytophaga/Flavobacterium/Bacteroides line of phylogenetic descent. Syst Appl Microbiol 21, 374-383.

Kim, K.-H., Im, W.-T. \& Lee, S.-T. (2008). Hymenobacter soli sp. nov., isolated from grass soil. Int J Syst Evol Microbiol 58, 941-945.

Kimura, M. (1980). A simple method for estimating evolutionary rates of base substitutions through comparative studies of nucleotide sequences. J Mol Evol 16, 111-120.

Kovács, N. (1956). Identification of Pseudomonas pyocyanea by the oxidase reaction. Nature 178, 703-704.

Kumar, S., Tamura, K. \& Nei, M. (2004). MEGA 3: integrated software for molecular evolutionary genetics analysis and sequence alignment. Brief Bioinform 5, 150-163.

Lane, D. J. (1991). 16S-23S rRNA sequencing. In Nucleic Acid Techniques in Bacterial Systematics, pp. 125-175. Edited by E. Stackebrandt \& M. Goodfellow. Chichester: Wiley.

Lin, Y.-C., Uemori, K., de Briel, D. A., Arunpairojana, V. \& Yokota, A. (2004). Zimmermannella helvola gen. nov., sp. nov., Zimmermannella alba sp. nov., Zimmermannella bifida sp. nov., Zimmermannella faecalis sp. nov. and Leucobacter albus sp. nov., novel members of the family Microbacteriaceae. Int J Syst Evol Microbiol 54, 1669-1676.

Mesbah, M., Premachandran, U. \& Whitman, W. B. (1989). Precise measurement of the $\mathrm{G}+\mathrm{C}$ content of deoxyribonucleic acid by highperformance liquid chromatography. Int J Syst Bacteriol 39, 159-167.

Saitou, N. \& Nei, M. (1987). The neighbor-joining method: a new method for reconstructing phylogenetic trees. Mol Biol Evol 4, 406425.

Smibert, R. M. \& Krieg, N. R. (1994). Phenotypic characterization. In Methods for General and Molecular Bacteriology, pp. 607-654. Edited by P. Gerhardt, R. G. E. Murray, W. A. Woods \& N. R. Krieg. Washington, DC: American Society for Microbiology.

Stackebrandt, E. \& Goebel, B. M. (1994). Taxonomic note: a place for DNA-DNA reassociation and $16 \mathrm{~S}$ rRNA sequence analysis in the present species definition in bacteriology. Int J Syst Bacteriol 44, 846849.

Thompson, J. D., Gibson, T. J., Plewniak, F., Jeanmougin, F. \& Higgins, D. G. (1997). The CLUSTAL_X windows interface: flexible strategies for multiple sequence alignment aided by quality analysis tools. Nucleic Acids Res 25, 4876-4882.

Tindall, B. J. (1990). A comparative study of the lipid composition of Halobacterium saccharovorum from various sources. Syst Appl Microbiol 13, 128-130. 
Ventosa, A., Marquez, M. C., Kocur, M. \& Tindall, B. J. (1993). Comparative study of "Micrococcus sp." strains CCM 168 and CCM 1405 and members of the genus Salinicoccus. Int J Syst Bacteriol 43, 245-248.

Xie, C. H. \& Yokota, A. (2003). Phylogenetic analysis of Lampropedia hyalina based on the 16S rRNA gene sequence. J Gen Appl Microbiol 49, 345-349.
Zhang, Q., Liu, C., Tang, Y., Zhou, G., Shen, P., Fang, C. \& Yokota, A. (2007). Hymenobacter xinjiangensis sp. nov., a radiation-resistant bacterium isolated from the desert of Xinjiang, China. Int J Syst Evol Microbiol 57, 1752-1756.

Zhang, G., Niu, F., Busse, H.-J., Ma, X., Liu, W., Dong, M., Feng, H., An, L. \& Cheng, G. (2008). Hymenobacter psychrotolerans sp. nov., isolated from the Qinghai-Tibet Plateau permafrost region. Int J Syst Evol Microbiol 58, 1215-1220. 